\title{
$\mathrm{Fe}$ 基耐熱合金 $\mathrm{A} 286$ 大形鍛造品の逆 $\mathrm{V}$ 偏析部 “崙 文 の機械的性質におよぼす $\mathrm{Ti}$ 量の影響

\author{
高野正義 ${ }^{*} \cdot$ 本庄武光 $*$ 土土友博 $* 2 \cdot$ 木下修司 $* 2$ \\ 竹田頼正 ${ }^{* 3} \cdot$ 藤田明次 $* 3 \cdot$ 藤川卓爾 $* 4 \cdot$ 肥爪彰夫 $* 5$
}

\section{Effect of Titanium Content on Mechanical Properties of "A" Segregation Region in Large A286 Iron-base Superalloy Forgings}

\author{
Masayoshi Kohno, Takemitsu Honjo, Tomohiro Tsuchiyama, Shushi Kinoshita, \\ Yorimasa TAKedA, Akitsugu Fujita, Takuya FujiKawa and Akio Hizume
}

\begin{abstract}
Synopsis :
A286 iron-base superalloy has been planned to be applied to rotor material of ultra-super critical steam turbine in which main steam temperature is $649^{\circ} \mathrm{C}$, because of its high strength at high temperatures. In this case, a large ESR ingot weighing about $40 \mathrm{t}$ is necessary. However, in the large ESR ingot of this material, "A" segregation is easily formed which may deteriorate the properties of the forgings.

Therefore, characteristics of " $A$ " segregation and mechanical properties of the segregated region, comparing with the normal region, in large A286 alloy forgings made from the $1000 \sim 1350 \mathrm{~mm}$ diameter ESR ingots with different $\mathrm{Ti}$ contents have been investigated. The following results are obtained;

1) Lowering Ti content is favorable for reducing " $A$ " segregation.

2) Tensile properties, creep rupture properties, high and low cycle fatigue strength except tensile ductilities below $200^{\circ} \mathrm{C}$ and low cycle fatigue strength in higher strain than $1.0 \%$ are not deteriorated by " $\mathrm{A}$ " segregation in A286 alloy with $1.9 \% \mathrm{Ti}$.
\end{abstract}

3) Lowering $\mathrm{Ti}$ content improves the tensile ductility and low cycle fatigue strength in higher strain range.

4) Influence of "A"segregation on mechanical properties can be well explained by the difference in hardness between normal and segregated regions after work hardening by each test.

Key words : A286 iron-base superalloy; ultra super critical steam turbine ; segregation; ESR ; Ti content ; mechanical properties.

\section{1. 緒 \\ 言}

現在, 火力発電プラントの高効率化を目的として, 蒸 気条件によって STEP-I および STEP-II の 2 段階 に分けて，超超臨界圧タービンの開発が進められてい $3^{122)}$. 蒸気温度の上昇により，このタービンに使用さ れる部品には, 従来材にくらべさらに高温強度の優れた 各種の材料が要求されている3).

従来, 蒸気タービンの主要部材であるロータ材として は，高温部には $\mathrm{CrMoV}$ 鋼あるいは $12 \mathrm{Cr}$ 鋼が使用さ
れているが, STEP-I タービンでは蒸気温度が $593^{\circ} \mathrm{C}$ まで上昇するため, クリープ強度を改善した改良 $12 \mathrm{Cr}$ 鋼が使用された ${ }^{4)}$ 。また，さらに蒸気温度の高い

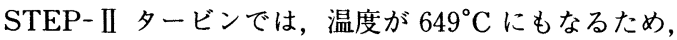
クリープ強度の点からオーステナイト系の $\mathrm{Fe}$ 基耐熱合 金が検討され，大形ロータとして適用できるよう改善さ れた改良 A286 合金が使用されることになった ${ }^{5)}$.

超超臨界圧 STEP- II タービンの実証試験には約 $12.5 \mathrm{t}$ の高中圧ロータが使用されるため, 約 $40 \mathrm{t}$ の大 形 ESR 鋳塊が必要になる. A286, Discaloy などの Fe

昭和 63 年 3 月本会講演大会にて発表 平成元年 11 月 20 日受付 (Received Nov. 20, 1989)

* (株)神戸製鋼所高砂鋳鍛鎆工場 (Steel Casting and Forging Plant, Takasago, Kobe Steel, Ltd., 2-3-1 Niihama Arai-cho Takasago 676)

*2 (株)神戸製鋼所高砂鋳鉭鋼工場 工博 (Steel Casting and Forging Plant, Takasago, Kobe Steel, Ltd.)

*3 三菱重工業(株)長崎研究所 (Nagasaki R \& D Center, Mitsubishi Heavy Industries, Ltd.)

*4 三菱重工業(株)長崎造船所 (Nagasaki Shipyard and Machinery Works, Mitsubishi Heavy Industries, Ltd.)

*5 三菱重工業(株)原動機事業本部 (現 : 神戸大学) (Power Systems Headquaters, Mitsubishi Heavy Industries, Ltd., Now Kobe University) 
Table 1. Chemical composition of tested materials (wt\%).

\begin{tabular}{c|cccccccccccc}
\hline & $\mathrm{C}$ & $\mathrm{Si}$ & $\mathrm{Mn}$ & $\mathrm{P}$ & $\mathrm{S}$ & $\mathrm{Ni}$ & $\mathrm{Cr}$ & $\mathrm{Mo}$ & $\mathrm{V}$ & $\mathrm{Al}$ & $\mathrm{Ti}$ & $\mathrm{B}$ \\
\hline $1.9 \mathrm{Ti}$ & 0.034 & 0.42 & 1.18 & 0.008 & 0.001 & 25.82 & 15.70 & 1.31 & 0.22 & 0.25 & 1.90 & 0.0063 \\
$1.6 \mathrm{Ti}$ & 0.012 & 0.10 & 0.55 & 0.012 & 0.001 & 25.82 & 14.95 & 1.21 & 0.26 & 0.22 & 1.58 & 0.0036 \\
$1.4 \mathrm{Ti}$ & 0.014 & 0.12 & 0.58 & 0.012 & 0.001 & 25.89 & 14.90 & 1.24 & 0.25 & 0.16 & 1.39 & 0.0038 \\
$1.1 \mathrm{Ti}$ & 0.021 & 0.16 & 0.48 & 0.011 & 0.001 & 25.95 & 14.62 & 1.30 & 0.18 & 0.13 & 1.13 & 0.0048 \\
\hline
\end{tabular}

基耐熱合金はフェライト系の鋼にくらべ高温強度は優れ ているが, 通常, ジェットエンジンあるいはガスタービ ンなどの小形部品として使用され，大形鍛造品の製造実 績はほとんどない.また，蒸気タービンロータとしては 約 $1.6 \mathrm{t}$ の小形ロータが Eddystone No. 1 タービンに使 用された例があるだけである6). そのため, 著者らは, 超超臨界圧 STEP- II タービン用ロータ材として, A286 合金大形鉔造品の製造技術を確立するための研究

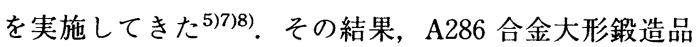
製造上の重要な問題点の一つとして, ESR 鋳塊の大形 化に伴う逆 V 偏析 (VAR, ESR 鋳塊では Freckle とも いう）の生成傾向の増加が指摘される.

逆 V 偏析の生成防止に関しては，まず， ESR 溶解条 件の適正化, すなわち, 凝固速度および冷却速度を速く することが重要であるが, ESR 鋳塊の大きさによって はそれだけでは不十分な場合がある。そのため, A286 合金の化学成分の検討を行い, 逆 $\mathrm{V}$ 偏析の軽減には $\mathrm{Ti}$ あるいは Si 量の低減が有効であることを示した5)8)。 た，桜井らも，同様の傾向を実験室的に明らかにしてい る $^{9) 10)}$.

そこで, Ti 量を変化させた $1000 〜 1350 \mathrm{~mm} \phi \mathrm{ESR}$ 鋳塊から製造したA286 合金大形鍛造品の性能を調査 し, 逆 V 偏析の性状および偏析部の機械的性質におよ ほす $\mathrm{Ti}$ 量の影響について検討した.

\section{2. 供試材および実験方法}

供試材はVODにより溶製した電極を ESR した後鍛 造したもので，その化学成分を Table 1 に示す. 1.9 $\mathrm{Ti}$ 材は通常の A286 合金の下限の Ti を含有し, 他の供 試材はさらに $\mathrm{Ti}$ 量を減少させている. なお, $\mathrm{Si}$ 量は 逆 V 偏析の軽減のためできるだけ低くおさえた。

$1.9 \mathrm{Ti}$ 材は $1000 \mathrm{~mm} \phi \mathrm{ESR}$ 鋳塊を $880 \mathrm{~mm} \phi$ まで鉔 造し，他の供試材は $1350 \mathrm{~mm} \phi \mathrm{ESR}$ 鋳塊を $950 \mathrm{~mm} \phi$ まで鍛造した軸材から, 正常部試験材および逆 V 偏析 を含む試験材を採取した. なお, 各供試材は, 途中に据 込み鍛錬を実施し, 鍛鍊比をほほ一定とした. 各供試材 には Table 2 に示す熱処理を施した. 溶体化処理時の 冷却は $950 \mathrm{~mm} \phi$ 軸材水冷時の中心の冷却曲線を想定し, 平均冷却速度を $220^{\circ} \mathrm{C} / \mathrm{h}$ とした。 また, 通常の $\mathrm{A} 286$
Table 2. Heat treatment conditions.

\begin{tabular}{c|l|c|c|c}
\hline & \multirow{2}{*}{$\begin{array}{c}\text { Solution } \\
\text { treatment }\end{array}$} & \multicolumn{3}{|c}{ Precipitation treatment } \\
\cline { 3 - 3 } & & $1 \mathrm{st}$ & 2nd & 3rd \\
\hline $1.9 \mathrm{Ti}$ & $1100^{\circ} \mathrm{C} \times 8 \mathrm{~h}$ & $820^{\circ} \mathrm{C} \times 20 \mathrm{~h}, \mathrm{FC}$ & & \\
$1.6 \mathrm{Ti}$ & & $810^{\circ} \mathrm{C} \times 20 \mathrm{~h}, \mathrm{FC}$ & $740^{\circ} \mathrm{C} \times$ & \\
$20 \mathrm{~h}, \mathrm{FC}$ & $650^{\circ} \mathrm{C} \times$ \\
$20 \mathrm{~h}, \mathrm{FC}$ \\
$1.4 \mathrm{Ti}$ & Cooling rate $;$ & $800^{\circ} \mathrm{C} \times 20 \mathrm{~h}, \mathrm{FC}$ & & \\
\cline { 3 - 3 } $1.1 \mathrm{Ti}$ & $220^{\circ} \mathrm{C} / \mathrm{h}$ & $780^{\circ} \mathrm{C} \times 20 \mathrm{~h}, \mathrm{FC}$ & & \\
\hline
\end{tabular}

合金の時効処理は $700 \sim 760^{\circ} \mathrm{C}$ の一段時効であるが, こ こではクリープ破断延性を改善するため，3段時効を採 用し5), Table 2 に示すように，1段時効温度を Ti 量 に応じて $820 〜 780^{\circ} \mathrm{C}$ に変化させた.

まず，各供試材について逆 V 偏析の性状を調査し, もっとも偏析の大きかった $1.9 \mathrm{Ti}$ 材について, 機械的 性質におよぼす逆 V 偏析の影響を調査した。ついで, 低 $\mathrm{Ti}$ 材について, 逆 V 偏析の影響が認められた室温 引張試験および室温低サイクル疲労試験を実施した。

逆 V 偏析の性状は光学顕微鏡および SEM による組 織観察, EPMAによる化学成分の分析および硬さ測定 により調査した，機械的性質は, 供試材の半径方向に採 取した正常部試験片および偏析線が試験片軸方向と直角 になるように製作した偏析部試験片をもちいて, 室温 $\sim 700^{\circ} \mathrm{C}$ の引張試験, クリープ破断試験 $\left(600,650^{\circ} \mathrm{C}\right)$, 高サイクルおよび低サイクル疲労試験 (室温, $650^{\circ} \mathrm{C}$ ) により調査した. 引張試験は $12.5 \mathrm{~mm} \phi$ 試験片をもちい て JIS G 0567 に基づき, クリープ破断試験は $6 \mathrm{~mm} \phi$ 試験片をもちい JIS Z 2272 に基づいて実施した. 高サ イクル疲労試験としては, $8 \mathrm{~mm} \phi$ 試験片をもちい JIS Z 2274 に基づいて, 回転曲げ度労試験を行った。また, 低サイクル疲労試験は WES 162 に基づいて,ひずみ速 度 $0.1 \% / \mathrm{s}$ の三角波による軸方向ひずみ制御引張圧縮試 験を行ったが, 試験機の都合上室温では $8 \mathrm{~mm} \phi, 650^{\circ} \mathrm{C}$ では $6 \mathrm{~mm} \phi$ 試験片を使用した。

\section{3. 実験結果および考察}

\section{$3 \cdot 1$ 逆 V 偏析の性状におよぼす Ti 量の影響}

逆 $\mathrm{V}$ 偏析は鍛造品の軸方向に平行にひも状に伸びて おり, その横断面の光学顕微鏡組織を Photo. 1 に示す. 逆 $\mathrm{V}$ 偏析は黒く腐食された部分であり， Ti 量の減少に 

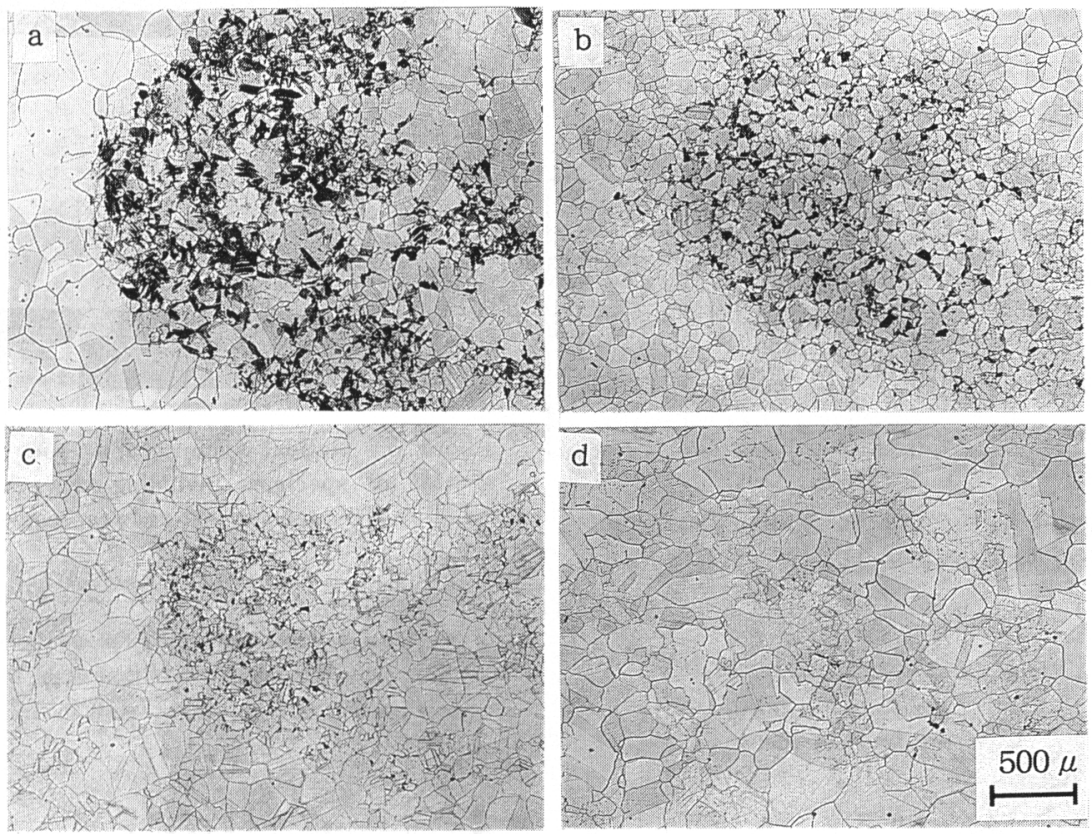

a : $1.9 \mathrm{Ti} \quad$ b : $1.6 \mathrm{Ti}$

c : $1.4 \mathrm{Ti} \quad \mathrm{d}: 1.1 \mathrm{Ti}$

Photo. 1. Optical micrographs of segregated regions in large A286 alloy forgings with different Ti contents.

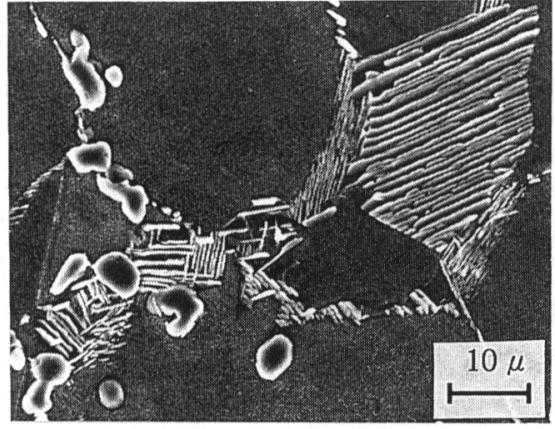

Photo. 2. Scanning electron micrograph of segregated region in large A286 alloy forging with $1.9 \%$ Ti.

伴ってその生成傾向は低下し，1.4 Ti 材では非常に軽 微になり，1.1 Ti 材では全く認められなくなる。また， その大きさも，1.9 Ti 材では直径約 2 2.5 mm 程度で あるが, $1.6 \mathrm{Ti}$ 材では約 $2 \mathrm{~mm}, 1.4 \mathrm{Ti}$ 材では約 1.5 $\mathrm{mm}$ と $\mathrm{Ti}$ 量の減少に伴って小さくなっている. Photo. 2 にはさらに高倍率で観察した $1.9 \mathrm{Ti}$ 材の逆 $\mathrm{V}$ 偏析部 の SEM 組織を示すが, $\eta$ 相, 未固溶炭窒化物および
Table 3. Results of EPMA analysis on normal and segregated regions in large A286 alloy forgings with different Ti contents (wt \%).

\begin{tabular}{c|ccc|ccc|ccc}
\hline & \multicolumn{3}{|c|}{$1.9 \mathrm{Ti}$} & \multicolumn{3}{c|}{$1.6 \mathrm{Ti}$} & \multicolumn{3}{c}{$1.4 \mathrm{Ti}$} \\
\cline { 2 - 10 } & $\mathrm{N}$ & $\mathrm{S}$ & $\mathrm{S} / \mathrm{N}$ & $\mathrm{N}$ & $\mathrm{S}$ & $\mathrm{S} / \mathrm{N}$ & $\mathrm{N}$ & $\mathrm{S}$ & $\mathrm{S} / \mathrm{N}$ \\
\hline $\mathrm{Si}$ & 0.47 & 0.90 & 1.91 & 0.17 & 0.24 & 1.41 & 0.16 & 0.25 & 1.56 \\
$\mathrm{Mn}$ & 1.20 & 1.44 & 1.20 & 0.59 & 0.69 & 1.17 & 0.61 & 0.68 & 1.12 \\
$\mathrm{Ni}$ & 25.9 & 27.0 & 1.04 & 25.5 & 26.9 & 1.05 & 24.6 & 27.0 & 1.09 \\
$\mathrm{Cr}$ & 15.9 & 15.4 & 0.97 & 15.3 & 14.8 & 0.97 & 15.2 & 15.1 & 0.99 \\
$\mathrm{Mo}$ & 1.33 & 1.90 & 1.43 & 1.22 & 1.60 & 1.31 & 1.17 & 1.62 & 1.38 \\
$\mathrm{Al}$ & 0.30 & 0.39 & 1.30 & 0.31 & 0.39 & 1.27 & 0.27 & 0.37 & 1.37 \\
$\mathrm{Ti}$ & 1.97 & 4.76 & 2.42 & 1.65 & 3.76 & 2.28 & 1.39 & 2.89 & 2.08 \\
$\mathrm{Fe}$ & 54.4 & 49.7 & 0.91 & 57.1 & 52.4 & 0.92 & 52.8 & 52.8 & 0.92 \\
\hline
\end{tabular}

Laves 相と思われる析出物が多数認められる.これらの 析出物は $\mathrm{Ti}$ 量の低下に伴って減少する。

Table 3 に正常部と逆 V 偏析部の EPMA による化学 成分の分析結果を示す。いずれの供試材においても，逆 $\mathrm{V}$ 偏析部には $\mathrm{Ti}, \mathrm{Si}, \mathrm{Mo}, \mathrm{Al}, \mathrm{Mn}$ が濃化し, $\mathrm{Fe}$ が 減少しているが, $\mathrm{Ni}, \mathrm{Cr}$ はほとんど変わらない. 特に, $\mathrm{Ti}$ および $\mathrm{Si}$ の偏析率 $(\mathrm{S} / \mathrm{N})$ が高くなっている. 供試 材によって含有量の異なる $\mathrm{Ti}, \mathrm{Si}$ および Mn の偏析率 は含有量が減少するにつれて低下するが, 含有量のほほ 等しい他の化学成分の偏析率はほとんど変わらない. 


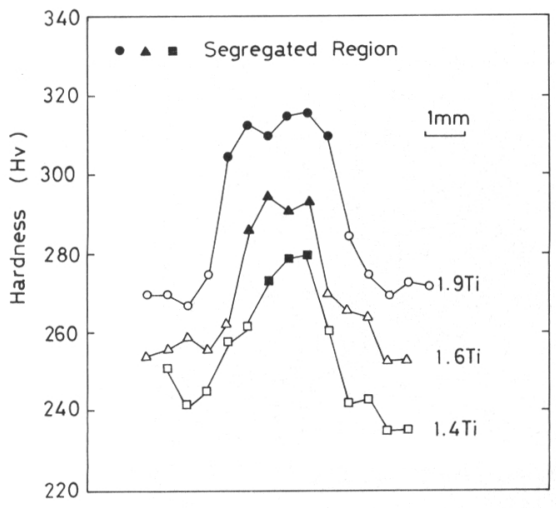

Fig. 1. Relation between hardness distribution of segregated regions in large A286 alloy forgings and Ti contents.

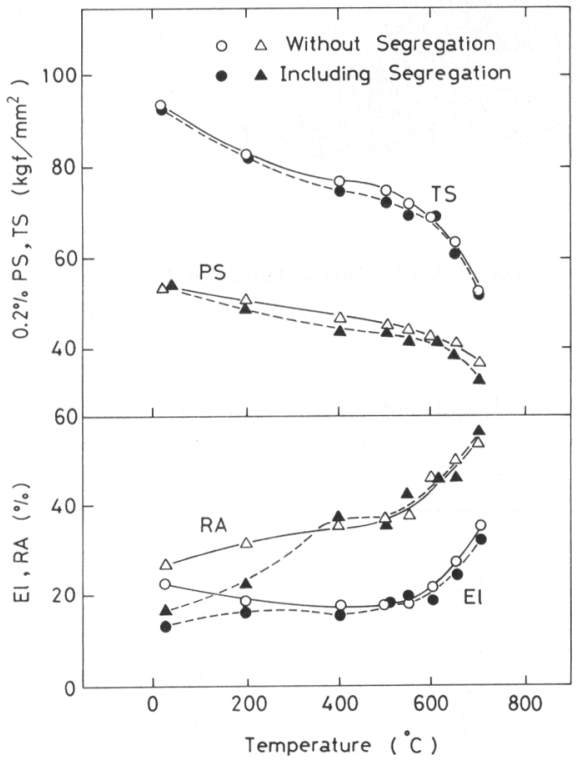

Fig. 2. Tensile properties of normal and segregated regions in $1.9 \mathrm{Ti}$ alloy at elevated temperatures.

Fig. 1 に逆 V 偏析部の硬さ分布と $\mathrm{Ti}$ 量の関係を示 す。正常部, 偏析部とも硬さは $\mathrm{Ti}$ 量の減少に伴って低 下し，偏析部では正常部にくらべ硬さが HV 40～30 上 昇している。 Ti 量の高い方が硬度差は大きく，また， 硬化部の幅も大きくなっている，偏析部の硬さの上昇は Table 3 の結果から考えて, 主として Ti の偏析による ものと考えられる.

\section{$3 \cdot 21.9 \mathrm{Ti}$ 材の機械的性質におよぼす逆 $\mathrm{V}$ 偏析の影響}

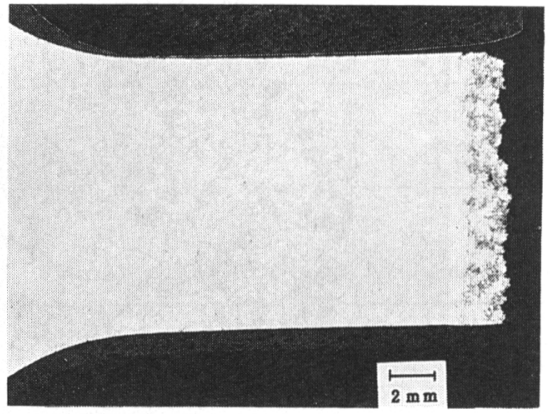

Photo. 3. Optical micrograph for longitudinal section of specimen including segregation in 1.9 $\mathrm{Ti}$ alloy after tensile test at room temperature.

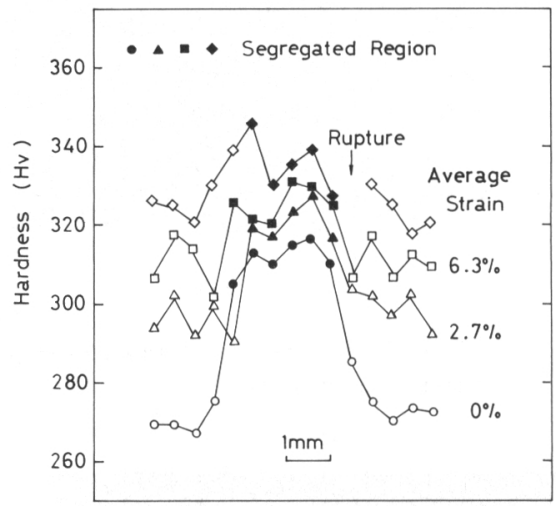

Fig. 3. Changes in hardness distrifution of segregated regions in $1.9 \mathrm{Ti}$ alloy with tensile strain.

Fig. 2 に正常部および逆 V 偏析を含む試験材の室温 から $700^{\circ} \mathrm{C}$ までの引張試験結果を示す。 $0.2 \%$ 耐力およ び引張強度は正常部と偏析部でほとんど差は認められな い.しかし，伸びおよび絞りは $400^{\circ} \mathrm{C}$ 以上ではほとん ど差はないが, 偏析部では $200^{\circ} \mathrm{C}$ および室温で急激に 低下する。これは $400^{\circ} \mathrm{C}$ 以上では正常部で破断してい るのに対し, $200^{\circ} \mathrm{C}$ 以下では, Photo. 3 に示すように偏 析部から破断しているためと考えられる.

$200^{\circ} \mathrm{C}$ 以下で偏析部より破断した原因を明らかにする ために, $1.9 \mathrm{Ti}$ 材の偏析を含む試験片に各量のひずみ を与えた後室温引張試験を中断し, 偏析部の硬度分布を 測定した結果を Fig. 3 に示す。なお，このひずみ量は 偏析を含む標点間距離 $(50 \mathrm{~mm})$ の平均ひずみであり, 正常部および偏析部の実際のひずみを表していない。同 図から, 初期硬さの低い正常部の硬度上昇が大きく, 破 断材では両者の硬さは非常に接近していることがわか 


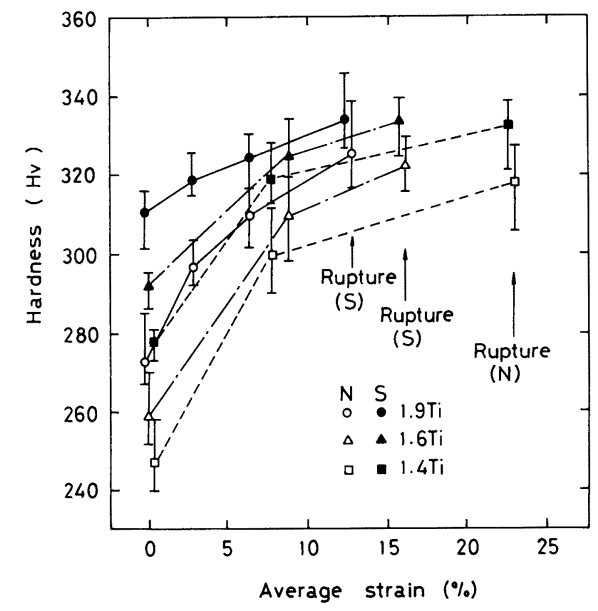

Fig. 4. Relation between hardness of normal regions $(\mathrm{N})$ and segregated regions $(\mathrm{S})$ in A286 alloys with different $\mathrm{Ti}$ contents and tensile strain.

る.

各供試材について同様の試験を行い, 正常部および偏 析部の硬さと平均ひずみ量の関係を求め Fig. 4 に示す. なお, 破断材については便宜上局部収縮を起こしていな い平行部の断面収縮量からひずみ量を換算した。引張試 験前は正常部にくらべ偏析部の硬さは高いが, 引張ひず みを与えると,加工硬化によりいずれの硬さも上昇する. $1.9 \mathrm{Ti}$ 材の場合, 破断までの平均硬化率は正常部で 4.1 $\mathrm{HV} / \%$, 偏析部で $1.8 \mathrm{HV} / \%$ であり, 偏析部にくらべ硬 化率の高い正常部の硬度上昇が大きく, 破断近くになる と正常部と偏析部の硬さは接近し, 延性の低い偏析部か ら破断したものと思われる.なお，この硬化率は前述の ようにみかけの硬化率であり, 偏析部の硬化率が低いの は, 偏析部の硬さが正常部より高いため実際のひずみ量 は低くなっていることが影響していると思われる.また， 前述したように, 偏析部には $\eta$ 相が多く析出しており, これはクリープ破断延性を向上させるが, 引張延性を低 下させるといわれており ${ }^{11)}$, これが偏析部の延性低下 の一因と推察される.

Fig. 5 に $1.9 \mathrm{Ti}$ 材の各種試験における破断後の偏析 部試験片の正常部および偏析部について室温で測定した 硬さを示す．硬さの測定結果にはばらつきがあるため, ある条件での硬さの平均值が比較する条件でのばらつき の範囲を超えて変化している場合に硬度差があると判定 することにした。この考え方によると, 室温引張試験の 破断材では正常部と偏析部の硬さは同等と判断される が, $650^{\circ} \mathrm{C}$ の高温引張試験の破断材については, 正常部

\begin{tabular}{|l|c|c|}
\hline \multirow{2}{*}{ Test Item } & Testing Condition & 260 \\
\hline Before Test & - & 280 \\
\hline \multirow{2}{*}{ Tensile Test } & $\mathrm{RT}$ & \\
\hline Creep Rupture & $600^{\circ} \mathrm{C}, 35 \mathrm{kgt} / \mathrm{mm}^{2}$ \\
Test & $650^{\circ} \mathrm{C}, 23.4 \mathrm{kgt} / \mathrm{mm}^{2}$
\end{tabular}

Fig. 5. Hardness of normal and segregated regions in $1.9 \mathrm{Ti}$ alloy after various mechanical tests.

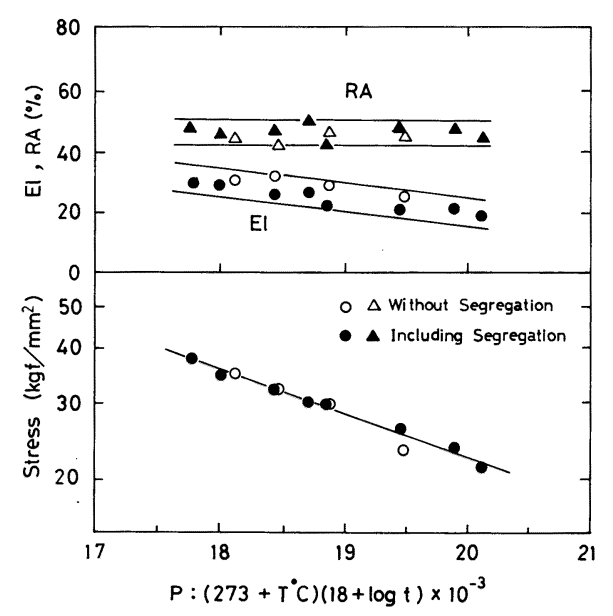

Fig. 6. Creep rupture properties of normal and segregated regions in $1.9 \mathrm{Ti}$ alloy.

より偏析部の硬さが高く, そのため正常部から破断した ものと考えられる.これは高温のため加工硬化が小さく, また, 偏析部も変形しやすいため, 正常部の硬さが偏析 部の硬さに達する前に破断にいたったためと考えられ る.

Fig. 6 に正常部および逆 V 偏析を含む試験材のク リープ破断試験結果をラーソンミラーパラメーターで整 理して示す. 破断はいずれの場合も正常部から起こり, クリープ破断強度および伸び, 絞りについても差は認め られない.

正常部および逆 V 偏析を含む試験材の室温および $650^{\circ} \mathrm{C}$ における高サイクル疲労試験結果を Fig. 7 に示 す.いずれの温度においても, 破断は正常部から起こり, 


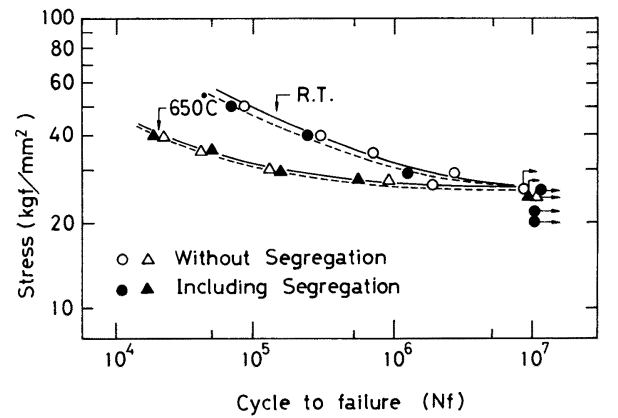

Fig. 7. High cycle fatigue strength of normal and segregated regions in $1.9 \mathrm{Ti}$ alloy.

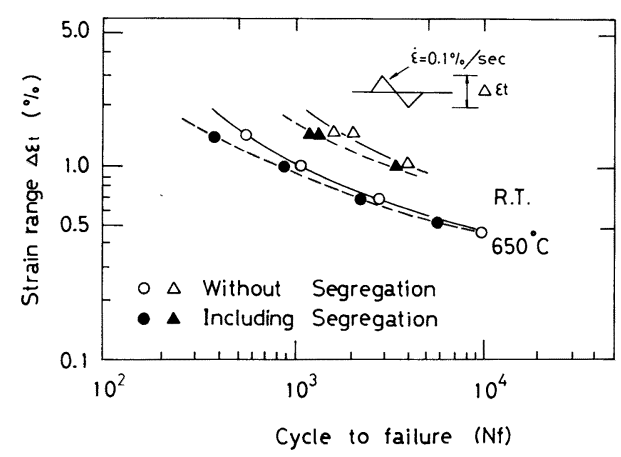

Fig. 8. Low cycle fatigue strength of normal and segregated regions in $1.9 \mathrm{Ti}$ alloy.

疲労寿命および度労限はほぼ同等であり, 高サイクル疲 労強度におよぼす逆 V 偏析の影響は認められない。

正常部および逆 V 偏析を含む試験材の低サイクル疲 労試験結果を Fig. 8 に示す.いずれの温度でも, 破断 は正常部から起こっているが, 全ひずみ範囲 $\Delta \varepsilon_{t}$ が $1 \%$ を超える高ひずみ側では偏析材の疲労寿命は正常部より 若干低いのに対し，それ以下の低ひずみ側では偏析の影 響は認められなくなる。

引張試験の場合と同様に, 各試験に対し硬さの变化を 検討した. 破断材の正常部㧍よび偏析部の硬さについて, 前述のような評価で比較すると, Fig. 5 から, 引張試験 を除くいずれの試験においても偏析部の硬さに変化は見 られないことがわかる.クリープ破断試験においては, 正常部では, $650^{\circ} \mathrm{C}-23.4 \mathrm{kgf} / \mathrm{mm}^{2}$ の場合には硬さの変 化は起こっていないのに対し, $600^{\circ} \mathrm{C}-35 \mathrm{kgf} / \mathrm{mm}^{2}$ と応 力の高い場合に若干硬化が認められるがそれほど大きく なく, 正常部と偏析部の硬度差はいずれも HV 30 以上 である。また, 高サイクル疲労試験では, 室温, $650^{\circ} \mathrm{C}$
いずれの場合も，正常部の加工硬化は認められない．以 上の結果，クリープ破断試験および高サイクル疲労試験 においては, 試験中の加工硬化が大きくなく, 試験前の 硬度差がそのまま残り，硬さの低い正常部から破断する ため, 正常部の性能がそのまま現れ，逆 V 偏析の影響 が認められなかったものと考えられる.

低サイクル疲労試験に打いては，正常部の硬度変化は $\Delta \varepsilon_{t}$ が $0.5 \%$ の低ひずみの場合には認められないのに対 し， $1.5 \%$ と高ひずみの場合には加工硬化が起こってい るが, 偏析部の硬さまでには達していない.したがって, いずれの場合にも正常部から破断するが, 偏析部試験片 の正常部の繰返しひずみ量は正常部試験片より高くな り，みかけ上偏析部試験片の強度が低くなり, 高ひずみ 側ほどその影響が大きくなるものと考えられる.

以上の結果, $1.9 \mathrm{Ti}$ 材の機械的性質に抒よぼす逆 $\mathrm{V}$ 偏析の影響としては, $200^{\circ} \mathrm{C}$ 以下の引張延性および高ひ ずみ範囲における低サイクル疲労強度を若干低下させる ものの，クリープ破断および高サイクル疲労強度に対し ては影響が認められないことが明らかになった。このよ うに試験の種類によって偏析の影響に差が生じた原因は 次のように考えられる．偏析部の機械的性質は破断時の 正常部と偏析部の硬度差にもっとも影響をうけ，室温引 張試験のように正常部の加工硬化が大きく, 硬度差が認 められなくなる場合には延性の低い偏析部から破断し, 延性は正常部試験片より低下する. 一方, 正常部の加工 硬化が小さく, 偏析部に比較し硬さが低い場合には, 正 常部から破断するため偏析の影響は小さい. しかし, 正 常部破断の場合でも, 低サイクル疲労試験の高ひずみ側 のように, 硬度差のため偏析部試験片の正常部ひずみが 正常部試験片より大きくなる場合には偏析の影響が現れ るものと考えられる.

\section{$3 \cdot 3$ 逆 V 偏析部の引張性質および低サイクル疲労強 度におよぼす Ti 量の影䈏}

$1.9 \mathrm{Ti}$ 材において，その機械的性質におよほす逆 V 偏析の影響が認められた室温引張試験および室温低サイ クル疲労試験 $\left(\Delta \varepsilon_{t}=1.5 \%\right)$ を, 逆 V 偏析の認められ た $1.6 \mathrm{Ti}, 1.4 \mathrm{Ti}$ について実施した.

$\mathrm{Ti}$ 量を変えた各供試材の正常部扰よび逆 V 偏析を含 む試験材の引張試験結果を Table 4 に示す. 正常部, 偏析部とも, 強度は $\mathrm{Ti}$ 量に比例して高くなっており, 逆に, 延性は低下している。偏析部試験片については, $1.9 \mathrm{Ti}$ 材の場合すべて偏析部から破断したが, $1.6 \mathrm{Ti}$ 材では 3 本中 1 本のみ, $1.4 \mathrm{Ti}$ 材はいずれも正常部か ら破断し, $\mathrm{Ti}$ 量の減少により逆 $\mathrm{V}$ 偏析の影響は低下し ていることが明らかである. 偏析部から破断した場合, 
Table 4. Tensile test results on normal and segregated regions in A286 alloys with different $\mathrm{Ti}$ contents.

\begin{tabular}{|c|c|c|c|c|c|c|}
\hline & Specimen & $\begin{array}{l}0.2 \% P S \\
(\mathrm{kgf} / \mathrm{mm})\end{array}$ & $\begin{array}{c}T S \\
(\mathrm{kgf} / \mathrm{mm})\end{array}$ & $\begin{array}{c}E l \\
(\%)\end{array}$ & $\begin{array}{l}R A \\
(\%)\end{array}$ & $\begin{array}{l}\text { Rupture } \\
\text { position }\end{array}$ \\
\hline \multirow{2}{*}{$1.9 \mathrm{Ti}$} & $\mathrm{N}$ & $\begin{array}{l}54.7 \\
53.3\end{array}$ & $\begin{array}{l}94.0 \\
93.9\end{array}$ & $\begin{array}{l}22 \\
24\end{array}$ & $\begin{array}{l}25 \\
26\end{array}$ & - \\
\hline & $\mathrm{S}$ & $\begin{array}{l}54.2 \\
53.4 \\
\end{array}$ & $\begin{array}{l}93.1 \\
93.7 \\
\end{array}$ & $\begin{array}{l}13 \\
17 \\
\end{array}$ & $\begin{array}{l}17 \\
18 \\
\end{array}$ & $\begin{array}{c}\text { Segregated } \\
\text { region }\end{array}$ \\
\hline \multirow{2}{*}{$1.6 \mathrm{Ti}$} & $\mathrm{N}$ & $\begin{array}{l}52.9 \\
53.2 \\
\end{array}$ & $\begin{array}{l}90.5 \\
91.2 \\
\end{array}$ & $\begin{array}{l}25 \\
26 \\
\end{array}$ & $\begin{array}{l}28 \\
30 \\
\end{array}$ & - \\
\hline & $\mathrm{S}$ & $\begin{array}{l}52.5 \\
51.8 \\
50.9\end{array}$ & $\begin{array}{l}91.3 \\
90.7 \\
89.2\end{array}$ & $\begin{array}{l}19 \\
24 \\
23\end{array}$ & $\begin{array}{l}22 \\
29 \\
28\end{array}$ & $\begin{array}{l}\text { Segregated } \\
\text { Normal } \\
\text { Normal }\end{array}$ \\
\hline \multirow{2}{*}{$1.4 \mathrm{Ti}$} & $\mathrm{N}$ & $\begin{array}{l}47.5 \\
46.2\end{array}$ & $\begin{array}{l}87.5 \\
86.4\end{array}$ & $\begin{array}{l}28 \\
29\end{array}$ & $\begin{array}{l}41 \\
42\end{array}$ & - \\
\hline & $\mathrm{S}$ & $\begin{array}{l}49.9 \\
47.9 \\
48.7\end{array}$ & $\begin{array}{l}88.4 \\
86.9 \\
87.6\end{array}$ & $\begin{array}{l}27 \\
28 \\
28\end{array}$ & $\begin{array}{l}42 \\
47 \\
46\end{array}$ & $\begin{array}{l}\text { Normal } \\
\text { region }\end{array}$ \\
\hline $1.1 \mathrm{Ti}$ & $\mathrm{N}$ & $\begin{array}{l}42.4 \\
41.6\end{array}$ & $\begin{array}{l}80.6 \\
79.1\end{array}$ & $\begin{array}{l}33 \\
32\end{array}$ & $\begin{array}{l}50 \\
48\end{array}$ & - \\
\hline \multicolumn{2}{|c|}{ Requirement } & $\geq 40.0$ & $\geq 75.0$ & $\geq 15$ & $\geq 18$ & - \\
\hline
\end{tabular}

$\mathrm{N}$ : Without segregation $\mathrm{S}$ : Including segregation

伸び，絞りは正常部破断材より低いが，強度の差は認め られない.

また，Table 4 には超超臨界圧 STEP-II タービンの 高温ロータに要求される引張性質も示してある. $1.9 \mathrm{Ti}$ 材の偏析部試験片の場合，伸びおよび絞りの要求值を満 足できない程度まで延性が低下しているが，1.6 Ti 材 では偏析部から破断しても十分要求值を満足する延性を 示している. $1.4 \mathrm{Ti}, 1.1 \mathrm{Ti}$ 材ではさらに延性の改善が 認められる。 なお, 強度は $\mathrm{Ti}$ 量の減少に伴って低下す るが, $1.1 \mathrm{Ti}$ 材でも要求值を満足している.

Fig. 4 に示したように，1.6 Ti および $1.4 \mathrm{Ti}$ 材にお いても，1.9 Ti 材と同様, 正常部の加工硬化の方が偏 析部のそれより大きく，破断時の速度差は小さくなって いる。すなわち，1.9 Ti，1.6 Ti 执よび $1.4 \mathrm{Ti}$ 材の破 断までの硬さの上昇は，それぞれ，正常部で HV 53，64， 71，偏析部で HV 24，42，55 であり，いずれも Ti 量 の低下とともに増加し, 破断時の硬さは正常部では $\mathrm{Ti}$ 量が少ないほど低い傾向を示しているが，偏析部は $\mathrm{Ti}$ 量にかかわらずほほ同じ硬さとなっている.したがって, 破断時には低 $\mathrm{Ti}$ 材ほど正常部と偏析部の硬度差があ り，このため低 $\mathrm{Ti}$ 材では偏析部から破断が起こりにく くなったものと考えられる. 低 $\mathrm{Ti}$ 材ほど硬化量が大き いのは，正常部，偏析部とも $\mathrm{Ti}$ 量が低くなるほど延性 が高く，破断までの変形量が大きくなったためと考えら れる。また, Table 3 に示したように，Ti 量が低いほ ど偏析部の $\mathrm{Ti}$ 量も低いため, 硬さも低く, $\eta$ 相の析出 も少なくなり, 偏析部の延性が改善されたものと推察さ

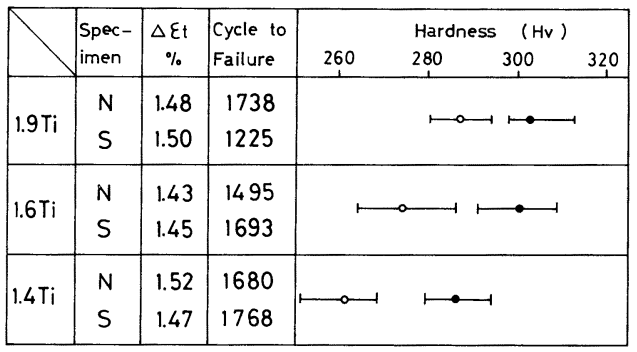

Note 1): $\mathrm{N}$---Without Segregation , S---Including Segregation $2): \longmapsto$ Normal Region, $\longmapsto$ Segregated Region

Fig. 9. Low cycle fatigue test results and hardness after test of normal and segregated regions in A286 alloys with different Ti contents.

れる.

Fig. 9 に $1.9 \mathrm{Ti} \sim 1.4 \mathrm{Ti}$ 材の正常部および逆 V 偏析 を含む試験材の室温での低サイクル疲労試験結果を示 す. $\Delta \varepsilon_{t}$ は $1.9 \mathrm{Ti}$ 材の試験において, 逆 $\mathrm{V}$ 偏析の影響 が認められた $1.5 \%$ の条件とした. $1.9 \mathrm{Ti}$ 材の破断 サイクルは 2 個のデータの平均值で示してある. 破断は すべて正常部から起こったが，前述のように $1.9 \mathrm{Ti}$ 材 では偏析部の低サイクル疲労強度は正常部より低かった のに対し，1.6 Ti および $1.4 \mathrm{Ti}$ 材はばらつきの範囲で 差はないものと判断される.

Fig. 9 には破断試験片の硬さ測定結果も示してある が, いずれの供試材についても正常部より偏析部の硬さ は高く，そのため強度の低い正常部から破断したものと 思われる．試験による硬度変化を前述のような考え方で 判定すると，正常部はいずれも HV 14１5 加工硬化し ているが, 偏析部については $\mathrm{Ti}$ 量によって異なった傾 向が認められる，すなわち，1.9 Ti 材の場合，硬さは 変化していないと判断されるのに対し，1.6 Ti および $1.4 \mathrm{Ti}$ 材では HV 8９ とわずかであるが加工硬化して いると判断される。 したがって，1.9 Ti 材の場合, 偏 析部はほとんど変形せず，繰返しひずみによる疲労損傷 をすべて正常部で受け持っているのに対し，低 Ti 材の 場合には偏析部も若干変形しているため, 偏析部試験片 の正常部のひずみ量が正常部試験片に近づき，低サイク ル疲労強度に差が認められなくなったものと考えられ る、また, $\mathrm{Ti}$ 量の減少による延性の改善および逆 $\mathrm{V}$ 偏 析の寸法の縮少もこの傾向を助長しているものと思われ る.

以上の結果, $\mathrm{Ti}$ 量を低くすることにより, 機械的性 質におよぼす逆 V 偏析の影響を軽減することが可能で あり，1.6 Ti 材では若干引張延性を低下させるものの 
要求值は満足し，1.4\%まで $\mathrm{Ti}$ を低下させることによ り, 引張りおよび低サイクル疲労特性におよぼす逆 $\mathrm{V}$ 偏析の影響は認められなくなることが明らかになった。 また，クリープ破断および高サイクル疲労特性におよぼ す影響もないものと考えられる．しかし， Ti 量の減少 は当然 A286 合金の強度低下をもたらす．超超臨界圧 STEP-II タービンの高温ロータに関しては，信頼性お よび設計上, 従来の A286 合金ほど高い強度は必要なく, Table 4 に示されているように, 引張強度は $1.1 \mathrm{Ti}$ 材 でも満足できる.また, 本ロータでもっとも重要なクリー プ破断強度は $649^{\circ} \mathrm{C} \times 10^{5} \mathrm{~h}$ で $11 \mathrm{kgf} / \mathrm{mm}^{2}$ 以上が要求 されているが, $1.1 \mathrm{Ti}$ 材でも満足することがすでに明 らかにされている5). さらに， $\mathrm{Ti}$ 量の減少は衝撃值の改 善および長時間加熱脆化に対しても有効であるといわれ ている5)12).

これらの成果に基づいて，40 t ESR 鋳塊から Ti 量 を $1.4 \%$ まで低滅させた改良 A286 合金ロー夕素材を製 造し, 要求性能を十分満足することが確認され, 現在, 超超臨界圧蒸気タービンの STEP-II 実証試験用とし て製作中である.

\section{4. 結}

\section{言}

Ti 量をかえた 1000〜1350 mm $\phi$ ESR 鋳塊から製造 した A286 合金大形鍛造品に生成した逆 V 偏析の性状 および偏析部の機械的性質におよぼす $\mathrm{Ti}$ 量の影響を調 査した結果, 次の結論が得られた.

1 ) A286 合金大形鍛造品の逆 V 偏析は Ti 量の減少 に伴って軽微になり， $\mathrm{Ti}$ 量が $1.1 \%$ になると全く認め られなくなる.

2 ) $1.9 \% \mathrm{Ti}$ を含む A286 合金大形般造品に関し, $200^{\circ} \mathrm{C}$ 以下の引張延性および全ひずみ範囲で $1.0 \%$ を超 える高ひずみ側の低サイクル疲労強度は逆 V 偏析の影 響を受けて低下するが，クリープ破断性質および高サイ クル疲労強度には影響が認められなかった。

3 ) $\mathrm{Ti}$ 量の減少により, 逆 V 偏析の度合が軽減され
るため, A286 合金の引張性質および低サイクル疲労強 度におよほす逆 V 偏析の影響は小さくなり，室温引張 延性に対しては $\mathrm{Ti}$ 量が $1.4 \%$, 室温低サイクル疲労強 度に対しては $1.6 \%$ 以下になると影響は認められなくな る.

4 )A286 合金の機械的性質におよぼす逆 V 偏析の影 響は破断時の正常部と偏析部の硬度差によって説明でき る. その硬度差は偏析の性状および試験の種類によって 異なる加工硬化によってきまる。

最後に，本研究に関し数々の御教示をいただいた(株) 神戸製鋼所・顧問鈴木章博士に深く感謝いたします。

\section{文献}

1) Y. NAKABAYASHI: 1st International Conference on Improved Coal-Fired Power Plants, Palo Alto (1986), p. 1

2 ) 伊坂 弘, 松村清貴: 材料とプロセス, 1 (1988), p. 730

3 ) 花田 剛, 肥爪彰夫, 藤川卓爾, 横田 宏, 竹田頼正, 国分孝友: 三菱重工技報, 25 (1988),p. 1

4 ) A. Hizume, Y. Takeda, $Y$. Takano, $H$. Yokota, $A$. SuZuki, $S$. Kinoshita, $M$. Kohno and T. Tsuchiyama: J. Engineering Materials and Technology, 109 (1987), p. 319

5 ) $K$. Furuya, $A$. Hizume, $Y$. Takeda, $T$. Fujikawa, $A$. Fujita, $S$. Kinoshita, $M$. Kohno, $T$. Honjo and $A$. Suzuki: 2nd International Conference on Improved Coal-Fired Power Plants, Palo Alto (1988), p. 59-1

6 ) W. E. Trumpler, Jr., E. A. Fox, $A . F$. Lebreton and $R$. B. Williamson: ASME Annual Muting, Atrantic City, 59-A-288 (1959)

7 ) $M$. Kohno, $T$. Honso, $S$. Kinoshita and $A$. Suzuki: 1 st International Conference on Improved Coal-Fired Power Plants, Palo Alto (1986), p. 6

8 ) S. Kinoshita, $M$. Kohno, $T$. Honjo, A. Suzuki, A. Hizume, $Y$. TAKEDA, $H$. Yokota and $A$. FuJiTA: International Conference in Advances in Material Technology for Fossile Power Plants, Chicago (1987), p. 195

9 ) 桜井 隆, 山田人久, 北村和夫, 竹之内朋夫: 鉄と鋼, 74 (1988), p. 2286

10) $S$. Shikano, $H$. Tsukada, $T$. Takenouchi, $J$. Ishizaka and T. OHASHI: 10 th International Forging Conference, Shefield (1985), p. 44.1

11）渡辺力藏, 九重常男: 鉄と鋼, 56 (1970), p. 1775

12）飯島活已, 山田範雄, 桐原誠信: 鉄と鋼, 71 (1985), p. 107 